\title{
Solid-state fermentation for production of a bioherbicide from Diaporthe sp. and its formulation to enhance the efficacy
}

\author{
Bruna de Oliveira Bastos ${ }^{1} \cdot$ Gabriel Antônio Deobald ${ }^{1} \cdot$ Thiarles Brun $^{1} \cdot$ \\ Valéria Dal Prá $^{1} \cdot$ Emanuele Junges $^{2} \cdot$ Raquel C. Kuhn $^{1} \cdot$ Aniela Kempka Pinto $^{3}$. \\ Marcio A. Mazutti ${ }^{1}$
}

Received: 4 November 2016/ Accepted: 23 January 2017/Published online: 8 June 2017

(C) Springer-Verlag Berlin Heidelberg 2017

\begin{abstract}
In this study, a bioherbicide was produced by solid-state fermentation (SSF) using Diaporthe sp. Adjuvants were employed in a formulation to enhance the herbicidal activity towards the target (Cucumis sativus). The study was divided into two steps: (1) the fermentation condition for bioherbicide production was assessed; (2) evaluation of different formulations containing palm oil, Tween ${ }^{\circledR} 80$ and $\operatorname{Span}^{\circledR} 80$, in order to increase phytotoxicity. In step 1 , the maximum herbicidal activity $(1.23 \%$ of the leaves had lesions) was obtained at $25^{\circ} \mathrm{C}$, moisture content of $50 \mathrm{wt} \%$, supplemented with $10 \mathrm{wt} \%$ of corn steep liquor and soybean bran and inoculum density of $15 \mathrm{wt} \%$. In step 2, the formulation containing $8.2 \mathrm{wt} \%$ of palm oil, $8.2 \mathrm{wt} \%$ of Tween ${ }^{\circledR} 80$ and $\operatorname{Span}^{\circledR} 80$, resulting in an HLB of 12.8 showed the highest phytotoxicity on the leaves. At this condition, dry matter and height of target were reduced about $36 \%$ in comparison with control. Diaporthe sp. has the potential to produce molecules with herbicidal activity and the use of adjuvants enhanced three times its efficiency.
\end{abstract}

Keywords Weeds $\cdot$ Adjuvants $\cdot$ Herbicide $\cdot$ Formulation

Marcio A. Mazutti

mazutti@ufsm.br

1 Department of Chemical Engineering, Federal University of Santa Maria, Av. Roraima, 1000, Santa Maria, RS 97105-900, Brazil

2 Instituto Federal de Educação, Ciência e Tecnologia Farroupilha, Rua 20 de Setembro, 2616, São Vicente do Sul, RS 97420-000, Brazil

3 Department of Food Engineering and Chemical Engineering, Santa Catarina State University (UDESC), SC 469, Km 01, Pinhalzinho 89870-000, Brazil

\section{Introduction}

Future weed management should consider new tools besides those existing, because modern agriculture constantly undergoes changes. A number of factors are interfering in the weed management, such as the elimination of some older herbicides, the high cost for development and registration of new chemical herbicides, lack of herbicides registered for small markets, the growing problems with resistant weeds to herbicides (Charudattan 2001). In addition, organic and conventional agriculture need tools to manage weeds and reduce their reliance on synthetic herbicides (Cordeau et al. 2016).

These facts lead to a growing search for new herbicides with safer toxicological and environmental profiles as well as with new modes of action (Dayan and Duke 2014). Studies based on molecular biology and natural products demonstrate that there are still many unexploited target sites (Duke and Dayan 2015) and natural phytotoxins may be the source for new herbicides (Dayan and Duke 2014; Cimmino et al. 2015).

Besides the potential of bioherbicides in modern agriculture, however, few have achieved long-term commercial success. Thirteen bioherbicides derived from microorganisms or natural molecules are currently available on the market: nine are based on fungi, three on bacteria and one based on active substance obtained from natural plant extract (Cordeau et al. 2016). The low number of registered and commercialized products may be related to the international barriers to introduce living organisms in foreign countries (Chutia et al. 2007). One alternative is the production of herbicidal compounds by fermentation, extraction from the fermented broth, and use of this compound in a more stable formulation (Brun et al. 2016). This strategy will not be limited on the continued survival of a given 
organism in an uncontrolled environment (Harding and Raizada 2015).

The production and marketing of bioproducts for agriculture involves the optimization of its production. Solidstate fermentation (SSF) has been the preferable process for production of secondary metabolites, because the fermentation media is based on agroindustrial residues with low cost and due to fact that SSF is better than submerged fermentation for production of complexes molecules (Pandey 2003). In addition, more robust and cost-effective fermentation and formulation downstream platforms are imperative for its overall commercialization by industry (Mascarin and Jaronski 2016).

Among the microorganisms with potential for production of molecules with herbicidal activity, Diaporthe sp. has shown interesting results (Souza et al. 2015, 2016; Pes et al. 2016; Briscoe 2014). Species of Diaporthe has been studied for production of molecules with antibacterial (Specian et al. 2012), antifungal (Prada et al. 2009) and for control of Phyllosticta citricarpa in citrus (Santos et al. 2016). In all studies reported above, submerged fermentation was the process employed for molecule production and the crude extract free of cell. It is known that the use of adjuvants enhance the efficiency of product. However, there are less number of studies focusing on production and formulation of bioherbicides containing microbial molecules in literature.

Based on these aspects, this study is focused on the bioherbicide production by solid-state fermentation (SSF) using Diaporthe sp. and its formulation to enhance the herbicidal activity in control of target (Cucumis sativus). The study was divided into two steps: (1) the fermentation condition for bioherbicide production was assessed; (2) evaluation of different formulations containing palm oil, Tween $^{\circledR} 80$ and $\operatorname{Span}^{\circledR} 80$ in order to increase phytotoxicity.

\section{Materials and methods}

\section{Materials}

Sugarcane bagasse was obtained in a microdistillery located at the Federal University of Santa Maria. The sample was dried, milled and sieved. Soybean bran was purchased in a local market. Corn steep liquor (CSL) was obtained from Ingredion (Mogi Guaçu, SP, Brazil) and it was used as received. Palm oil (Elaeis guineensis) was provided by the industry of processing of oils and derivatives Agropalma (Tailândia, PA, Brazil). Other chemicals namely, $\left(\mathrm{NH}_{4}\right)_{2} \mathrm{SO}_{4}, \mathrm{FeSO}_{4} \cdot 7 \mathrm{H}_{2} \mathrm{O}, \mathrm{MnSO}_{4} \cdot \mathrm{H}_{2} \mathrm{O}, \mathrm{MgSO}_{4}$, Tween ${ }^{\circledR}$ 80 (polyoxyethylene sorbitan monooleate) and $\mathrm{Span}^{\circledR} 80$ (sorbitan monooleate) were purchase from Sigma-Aldrich.

\section{Microorganism and inoculum}

The strain used in this study was Diaporthe sp., previously isolated by Souza et al. (2016). The culture was maintained in a potato dextrose agar (PDA) at $4{ }^{\circ} \mathrm{C}$ and subcultured every 15 days. Cell production for pre-inoculum was incubated in a petri dish containing PDA for 8 days at $28{ }^{\circ} \mathrm{C}$. For inoculum, two discs of $6 \mathrm{~mm}$ of fungal mycelium were transferred to a $250-\mathrm{mL}$ Erlenmeyer flask contained $100 \mathrm{~mL}$ of medium composed $\left(\mathrm{g} \mathrm{L}^{-1}\right)$ : glucose 10.0, peptone 7.5, yeast extract 2.0, $\mathrm{NH}_{4} 2 \mathrm{SO}_{4} 1.0$, $\mathrm{FeSO}_{4} \cdot 7 \mathrm{H}_{2} \mathrm{O}$ 1.0, $\mathrm{MnSO}_{4} \cdot \mathrm{H}_{2} \mathrm{O} 1.0$ and $\mathrm{MgSO}_{4}$ 0.5. The flasks were maintained at $28{ }^{\circ} \mathrm{C}, 120 \mathrm{rpm}$ for 7 days (Innova 44R, New Brunswick) (Souza et al. 2015).

\section{Solid-state fermentation}

Fermentations were carried out in conical flasks $(500 \mathrm{~mL})$ containing $10 \mathrm{~g}$ of solid substrate. Before the fermentations, the solid substrate was supplemented (corn steep liquor-CSL and soybean bran) and the moisture content adjusted at a specified level. Each flask was covered with hydrophobic cotton and autoclaved at $121{ }^{\circ} \mathrm{C}$ for $20 \mathrm{~min}$. After cooling, each flask was inoculated using a specific volume of inoculum. The fermentations were carried out for 7 days in a chamber with temperature and humidity control (POL-EKO, model KK 350). After the end of fermentation, the bioactive compounds of each assay were extracted using $100 \mathrm{~mL}$ of distilled water in an orbital shaker at $100 \mathrm{rpm}$ and $28{ }^{\circ} \mathrm{C}$ during $1 \mathrm{~h}$ (Innova 44, New Brunswick Scientific). The broth obtained from the extraction was filtered and stored for further use in the bioassays.

The variables and ranges studied in this step were temperature $\left(25-35^{\circ} \mathrm{C}\right)$, moisture content $(50-75 \mathrm{wt} \%)$, concentration of CSL (0-10 wt\%), concentration of soybean bran (0-10 wt\%) and inoculum density (5-15 wt\%) by means of a Plackett-Burman design with 12 runs plus three central points (PB12).

\section{Formulation of bioherbicide}

The formulation of bioherbicide was studied at the best condition of PB12 to increase its efficiency. At this step were used two surfactants with different hydrophiliclipophilic balance (HLB) $\left(\operatorname{Span}^{\circledR} 80-\mathrm{HLB}=4.3\right.$ and Tween $^{\circledR}$ 80-HLB $=15.0$ ) and palm oil as adjuvants. These adjuvants were combined to obtain stable palm oil in-water emulsion using an ultra-turrax.

Palm oil and span 80 (oil phase) and bioherbicide and tween 80 (aqueous phase) were homogenized separately in ultra-turrax for $1 \mathrm{~min}$ at $7000 \mathrm{rpm}$. In the following, oil phase was slowly added in aqueous phase under ultra- 
Table 1 Matrix of the PB12 design for selection of the best condition for production of bioherbicide by solid-state fermentation

\begin{tabular}{|c|c|c|c|c|c|c|}
\hline Runs & Temperature $\left({ }^{\circ} \mathrm{C}\right)$ & Moisture (wt $\%$ ) & $\operatorname{CSL}(\mathrm{wt} \%)$ & $\mathrm{SB}(\mathrm{wt} \%)$ & Inoculum (wt\%) & Damage of leaves $(\%)$ \\
\hline Water & - & - & - & - & 0 & $0.0 \mathrm{~g}^{*}$ \\
\hline $\mathrm{T} 1$ & 35 & 50 & 10 & 0 & 5 & $0.36 \mathrm{~d}$ \\
\hline $\mathrm{T} 2$ & 35 & 75 & 0 & 10 & 5 & $0.28 \mathrm{~d}$ \\
\hline T3 & 25 & 75 & 10 & 0 & 15 & $0.14 \mathrm{e}$ \\
\hline $\mathrm{T} 4$ & 35 & 50 & 10 & 10 & 5 & $0.89 \mathrm{~b}$ \\
\hline T5 & 35 & 75 & 0 & 10 & 15 & $0.62 \mathrm{c}$ \\
\hline T6 & 35 & 75 & 10 & 0 & 15 & $1.01 \mathrm{~b}$ \\
\hline $\mathrm{T} 7$ & 25 & 75 & 10 & 10 & 5 & $0.04 \mathrm{f}$ \\
\hline $\mathrm{T} 8$ & 25 & 50 & 10 & 10 & 15 & $1.23 \mathrm{a}$ \\
\hline T9 & 25 & 50 & 0 & 10 & 15 & $0.94 \mathrm{~b}$ \\
\hline $\mathrm{T} 10$ & 35 & 50 & 0 & 0 & 15 & $0.52 \mathrm{c}$ \\
\hline $\mathrm{T} 11$ & 25 & 75 & 0 & 0 & 5 & $0.24 \mathrm{~d}$ \\
\hline $\mathrm{T} 12$ & 25 & 50 & 0 & 0 & 5 & $0.25 \mathrm{~d}$ \\
\hline T13 & 30 & 62.5 & 5 & 5 & 10 & $0.02 \mathrm{~g}$ \\
\hline T14 & 30 & 62.5 & 5 & 5 & 10 & $0.01 \mathrm{~g}$ \\
\hline $\mathrm{T} 15$ & 30 & 62.5 & 5 & 5 & 10 & $0.01 \mathrm{~g}$ \\
\hline
\end{tabular}

* Mean followed by the same letter in the column did not differ statistically by the Scott-Knott's test at $95 \%$ of confidence level $(p<0.05)$

Table 2 Matrix of the DCCR to evaluate the influence of different formulations on the height, dry matter and phytotoxicity of target

\begin{tabular}{|c|c|c|c|c|c|c|c|c|c|c|}
\hline \multirow[t]{2}{*}{ Treatments } & \multicolumn{3}{|c|}{ Real and coded values } & \multicolumn{4}{|c|}{ Mass of components } & \multirow{2}{*}{$\begin{array}{l}\text { Plant height } \\
(\mathrm{cm})\end{array}$} & \multirow[t]{2}{*}{ Phytotoxicity } & \multirow{2}{*}{$\begin{array}{l}\text { Dry } \\
\text { matter }(\mathrm{g})\end{array}$} \\
\hline & $\begin{array}{l}\text { Palm oil } \\
\text { (wt } \%)\end{array}$ & $\begin{array}{l}\text { Surfactant } \\
(\mathrm{wt} \%)\end{array}$ & EHL (-) & $\begin{array}{l}\text { Palm oil } \\
\text { (g) }\end{array}$ & $\begin{array}{l}\operatorname{Span}^{\circledR} \\
80(\mathrm{~g})\end{array}$ & $\begin{array}{l}\text { Tween }^{(B)} \\
80(\mathrm{~g})\end{array}$ & $\begin{array}{l}\text { Bioherbicide } \\
\text { (g) }\end{array}$ & & & \\
\hline Water & - & - & - & - & - & - & - & $9.1 \mathrm{a}$ & $1 \mathrm{a}$ & $0.810 \mathrm{a}$ \\
\hline $100 \%$ bioherbicide & - & - & - & - & - & - & 25.000 & $6.9 \mathrm{c}$ & $3 \mathrm{c}$ & $0.560 \mathrm{~b}$ \\
\hline $\mathrm{T} 1$ & $2.8(-1)$ & $2.8(-1)$ & $6.5(-1)$ & 0.700 & 0.556 & 0.144 & 23.600 & $7.6 \mathrm{~b}$ & $3 \mathrm{c}$ & $0.770 \mathrm{a}$ \\
\hline $\mathrm{T} 2$ & $8.2(1)$ & $2.8(-1)$ & $6.5(-1)$ & 2.050 & 0.556 & 0.144 & 22.250 & $8.2 \mathrm{a}$ & $3 \mathrm{c}$ & $0.820 \mathrm{a}$ \\
\hline $\mathrm{T} 3$ & $2.8(-1)$ & $8.2(1)$ & $6.5(-1)$ & 0.700 & 1.629 & 0.421 & 22.250 & $8.0 \mathrm{~b}$ & $4 \mathrm{~d}$ & $0.720 \mathrm{a}$ \\
\hline $\mathrm{T} 4$ & $8.2(1)$ & $8.2(1)$ & $6.5(-1)$ & 2.050 & 1.629 & 0.421 & 20.900 & $7.5 \mathrm{~b}$ & $5 \mathrm{e}$ & $0.730 \mathrm{a}$ \\
\hline T5 & $2.8(-1)$ & $2.8(-1)$ & $12.8(1)$ & 0.700 & 0.144 & 0.556 & 23.600 & $7.1 \mathrm{c}$ & $5 \mathrm{e}$ & $0.590 \mathrm{~b}$ \\
\hline T6 & $8.2(1)$ & $2.8(-1)$ & $12.8(1)$ & 2.050 & 0.144 & 0.556 & 22.250 & $7.6 \mathrm{~b}$ & $4 \mathrm{~d}$ & $0.710 \mathrm{a}$ \\
\hline $\mathrm{T} 7$ & $2.8(-1)$ & $8.2(1)$ & 12.8 (1) & 0.700 & 0.421 & 1.629 & 22.250 & $7.2 \mathrm{c}$ & $5 \mathrm{e}$ & $0.640 \mathrm{~b}$ \\
\hline $\mathrm{T} 8$ & $8.2(1)$ & $8.2(1)$ & $12.8(1)$ & 2.050 & 0.421 & 1.629 & 20.900 & $5.9 \mathrm{~d}$ & $7 \mathrm{f}$ & $0.570 \mathrm{~b}$ \\
\hline T9 & $1(-1.68)$ & $5.5(0)$ & $9.7(0)$ & 0.250 & 0.681 & 0.694 & 23.375 & $8.7 \mathrm{a}$ & $3 \mathrm{c}$ & $0.760 \mathrm{a}$ \\
\hline $\mathrm{T} 10$ & $10(1.68)$ & $5.5(0)$ & $9.7(0)$ & 2.500 & 0.681 & 0.694 & 21.125 & $7.1 \mathrm{c}$ & $5 \mathrm{e}$ & $0.610 \mathrm{~b}$ \\
\hline $\mathrm{T} 11$ & $5.5(0)$ & $1(-1.68)$ & $9.7(0)$ & 1.375 & 0.124 & 0.126 & 23.375 & $7.3 \mathrm{c}$ & $3 \mathrm{c}$ & $0.720 \mathrm{a}$ \\
\hline $\mathrm{T} 12$ & $5.5(0)$ & $10(1.68)$ & $9.7(0)$ & 1.375 & 1.238 & 1.262 & 21.125 & $7.8 \mathrm{~b}$ & $5 \mathrm{e}$ & $0.810 \mathrm{a}$ \\
\hline $\mathrm{T} 13$ & $5.5(0)$ & $5.5(0)$ & $4.3(-1.68)$ & 1.375 & 1.375 & 0.000 & 22.250 & $7.6 \mathrm{~b}$ & $2 \mathrm{~b}$ & $0.890 \mathrm{a}$ \\
\hline $\mathrm{T} 14$ & $5.5(0)$ & $5.5(0)$ & 15 (1.68) & 1.375 & 0.000 & 1.375 & 22.250 & $5.8 \mathrm{~d}$ & $8 \mathrm{~g}$ & $0.510 \mathrm{~b}$ \\
\hline $\mathrm{T} 15$ & $5.5(0)$ & $5.5(0)$ & $9.7(0)$ & 1.375 & 0.681 & 0.694 & 22.250 & $7.7 \mathrm{~b}$ & $5 \mathrm{e}$ & $0.590 \mathrm{~b}$ \\
\hline $\mathrm{T} 16$ & $5.5(0)$ & $5.5(0)$ & $9.7(0)$ & 1.375 & 0.681 & 0.694 & 22.250 & $7.7 \mathrm{~b}$ & $5 \mathrm{e}$ & $0.650 \mathrm{~b}$ \\
\hline T17 & $5.5(0)$ & $5.5(0)$ & $9.7(0)$ & 1.375 & 0.681 & 0.694 & 22.250 & $8.4 \mathrm{a}$ & $5 \mathrm{e}$ & $0.690 \mathrm{a}$ \\
\hline
\end{tabular}

Mean followed by the same letter in the column did not differ statistically by the Scott-Knott's test at $95 \%$ of confidence level $(p<0.05)$ 


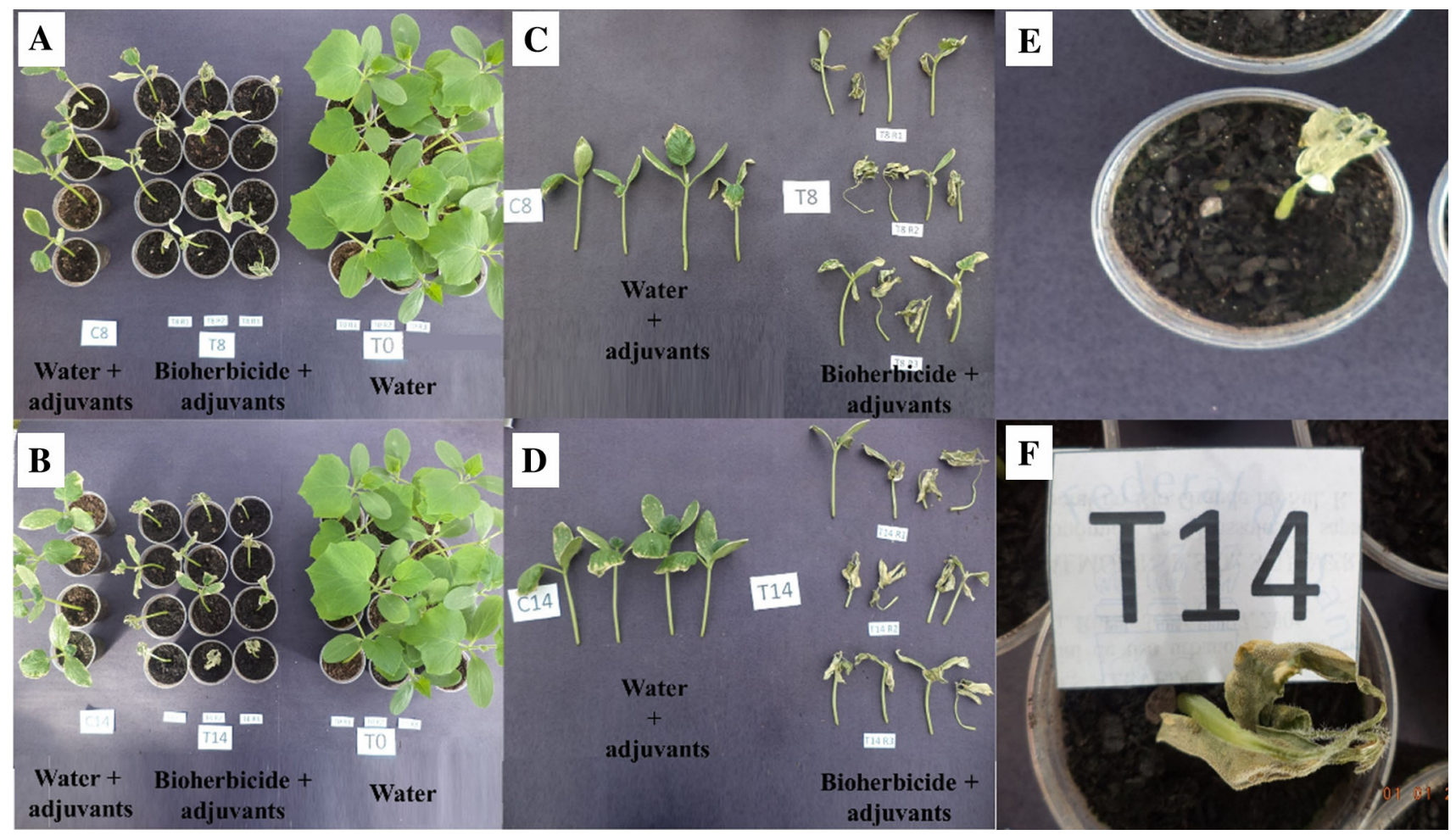

Fig. 1 Comparison of phytotoxic effect among formulations $8(\mathbf{a}, \mathbf{c})$ and $14(\mathbf{b}, \mathbf{d})$ in relation to treatment using water and water + adjuvant. Highlight of the phytotoxic effect in the formulation 8 (e) and 14 (f)

Fig. 2 Pareto chart expressing the linear, quadratic and interaction effects of independent variables of formulation in the phytotoxicity

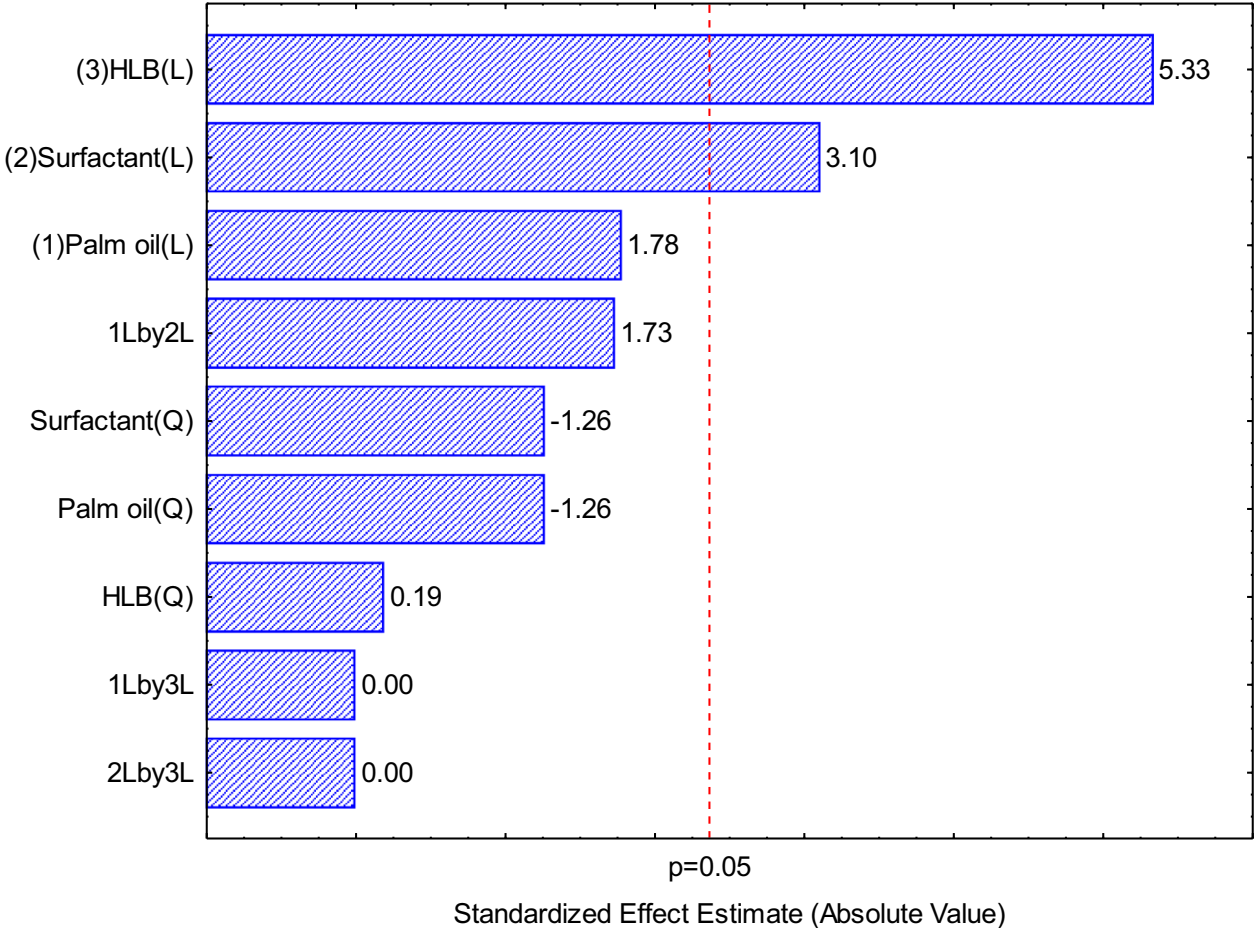

Standardized Effect Estimate (Absolute Value)

(1-10 wt $\%)$, emulsifier concentration $(1-10 \% \mathrm{w} / \mathrm{w})$ and hydrophilic-lipophilic balance (HLB) (4.3-15) by means of a central composite rotational design (CCRD). The (palm oil + bioherbicide + surfactants) was $25 \mathrm{~g}$. The variables studied in this step were oil concentration 


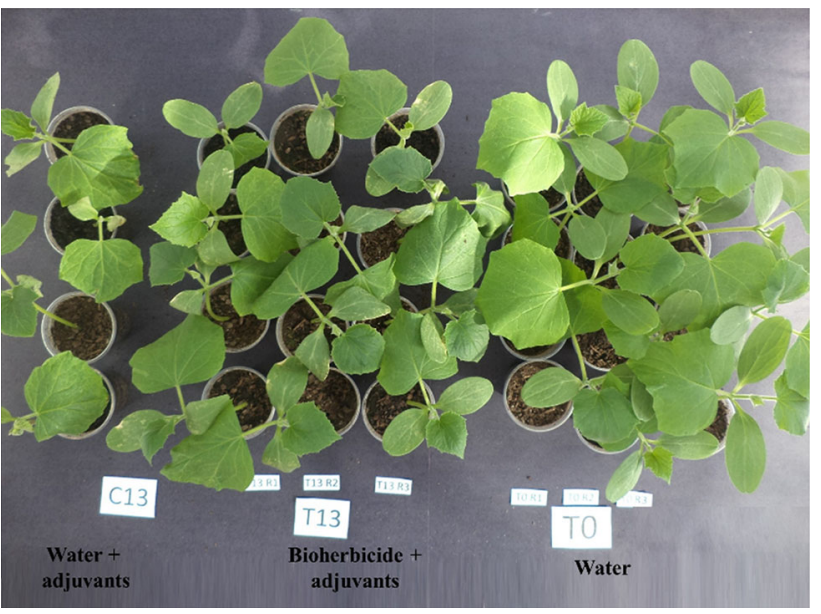

Fig. 3 Phytotoxicity presented by the target in the treatment 13

efficiency of the formulations was determined in the bioassays.

\section{Bioassays}

The herbicidal activity was determined using $C$. sativus as target plant. This specie was used in the bioassays because they have high sensitivity to phytotoxic compounds and is an easy-to-grow plant. Three seeds were sown in a plastic cup $(180 \mathrm{~mL})$ containing commercial substrate (Mecplant ${ }^{\circledR}$ ) without any treatment. After the emergence, only one plant was maintained per vessel, being cultivated for 7 days in a greenhouse located at the Federal University of Santa Maria (Santa Maria, Brazil).

Each treatment was composed of 12 plants with four repetitions. A volume of $3 \mathrm{~mL}$ of bioherbicide was applied at the same time in each bioassay using a garden sprayer. Control assays were performed using water instead of bioherbicide. Fourteen days after the application, plant injury was visually estimated in comparison to controls, where 9 represents complete plant death and 1 represents no effect (EWRC 1964). In addition, it was determined the dry matter and height of plants.

\section{Statistical analysis}

All statistical analyses were performed using Statistica 8.0 software (Statsoft Inc., Tulsa, OK, USA), considering a 90\% significance level. Statistical differences between treatments were determined by one-way analysis of variance and means separated using the least significant difference test $(p<0.05)$.

\section{Results and discussion}

\section{Solid-state fermentation}

Table 1 presents the results referring the definition of the best condition for bioherbicide production by solid-state fermentation. Fermented broth of Diaporthe sp. present herbicidal effect, since damage in the leaves of target was verified in all fermentations of the PB12. The highest percentage of damage in leaves of target occurred at run 8 $(1.23 \%)$, differing statistically from the other fermentations.

The injuries caused by metabolites of the fungus Diaporthe sp. were predominantly chlorosis verified at the site of contact of the bioherbicide with the leaf. Similar symptom was verified in previous studies of group referring to application of metabolites of Diaporthe sp. obtained by submerged fermentation (Souza et al. 2015; Pes et al. 2016). Chlorosis also was found by Varejão et al. (2013) when evaluating the effects of fermented broth of $A l$ ternaria euphorbiicola in leaves of Euphorbia heterophylla.

The effect of each variable on the percentage of damage on the leaves of target was calculated, and only inoculum density showed statistical significance $(p<0.1)$ (data not shown) with positive effect. This result is coherent since lower inoculum density cannot produce enough biomass to produce the biomolecules (Sanghi et al. 2008; Selvakumar and Pandey 1999). From the PB12 design, the highest herbicidal activity was obtained when fermentation was carried out at $25{ }^{\circ} \mathrm{C}$, moisture content of $50 \mathrm{wt} \%, 10 \mathrm{wt} \%$ of corn steep liquor and soybean bran and $15 \mathrm{wt} \%$ of inoculum density. For this reason, this condition was fixed for the next step of study.

\section{Formulation}

The use of adjuvants was studied as an alternative to improve the efficiency of bioherbicide, since crude broth presented low percent of injury in the target. Table 2 shows the results referring to the herbicidal activity, height and dry matter of plants obtained in the formulations of the CCRD. The use of adjuvants at some specific formulations increased the efficiency of bioherbicide. The highest phytotoxicity was observed in treatment 14 , being attributed level 8 of the EWRC classification that corresponds to extremely serious damage, leaving small green areas in plants. Treatment 8 also presented a high level of damage. 
Fig. 4 Height of plants (cm) obtained in the 17 formulations and its comparison with treatments using water and water + adjuvants. Same letter in the column did not differ statistically by the Scott-Knott's test at $95 \%$ of confidence level $(p<0.05)$
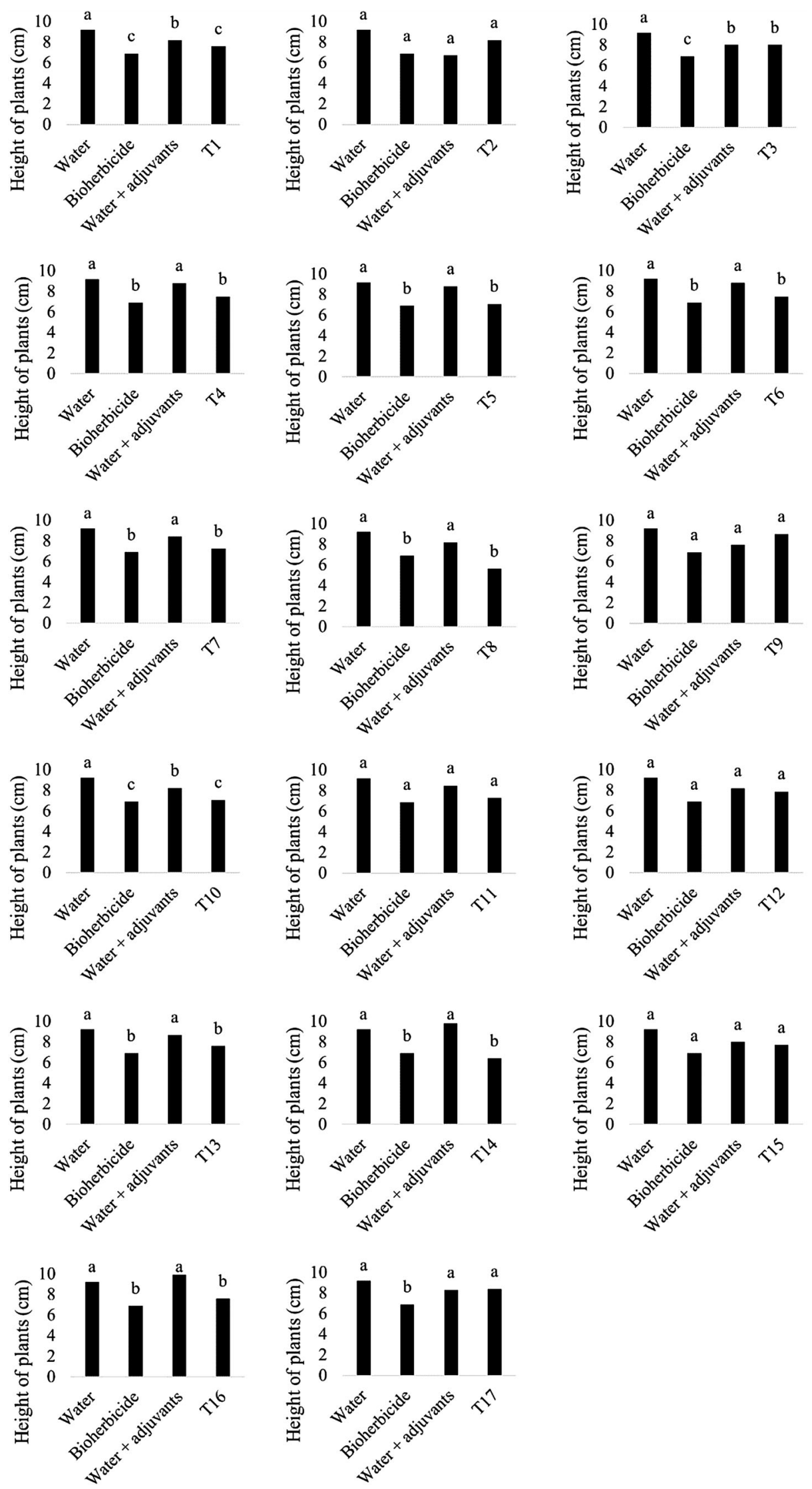


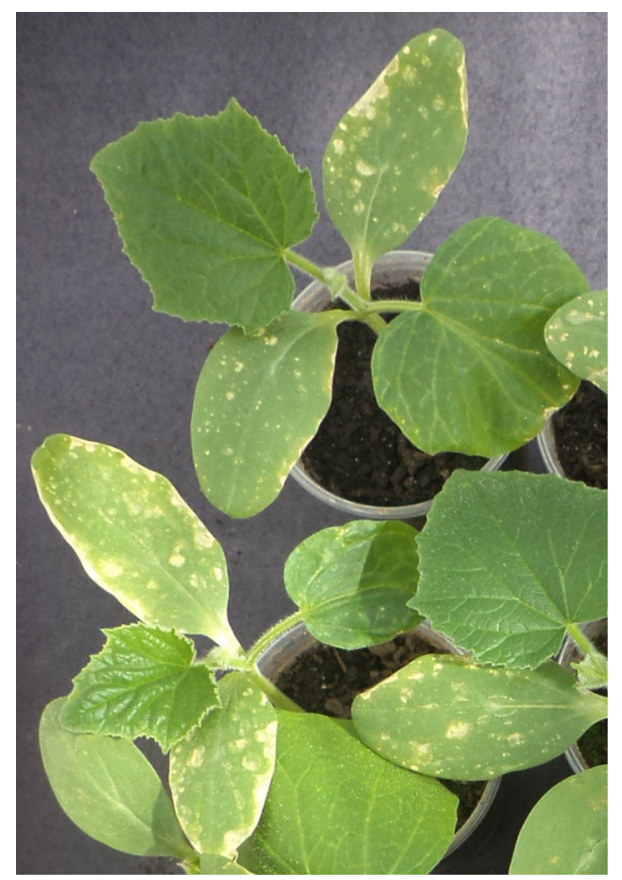

Fig. 5 Damage caused in the target due to application of bioherbicide without adjuvants

The phytotoxic effects of these treatments on target are shown in Fig. 1.

Data referring to phytotoxicity were used to compute the linear, interaction and quadratic effects of independent variables, which are presented in Fig. 2. Only surfactant concentration and HLB were statistically significant $(p<0.05)$ in the range evaluated, presenting a positive effect on the response. This result suggests that the molecules produced by the fungus are hydrophilic, since the formulations with high HLB values were the best.

Absorption of herbicides on plants is mainly through the cuticle of the leaf. Lipophilic herbicide penetrates through the cuticle by simple molecular diffusion through the waxy layer. Hydrophilic herbicides are also able to enter the plant by the surface of the cuticle by simple diffusion, but this permeability is reduced due to its low partitioning (Hess and Foy 2000). So, the use of a formulation with high HLB value will increase the hydration of cuticle, promoting a better permeability of hydrophilic herbicides onto the leaves, which increases the herbicidal rate of diffusion in a constant concentration gradient (Hess and
Foy 2000; Behrens 1964). Weaver (2009) reported that the HLB value of an adjuvant might increase the bioactivity of a herbicide and improve the chemical properties of a formulation.

The hypothesis raised above is corroborated by analyzing the treatment 13 (HLB 4.3). In this formulation, only palm oil and $\operatorname{Span}^{\circledR} 80$ were used. As $\operatorname{Span}^{\circledR} 80$ is a surfactant with lipophilic characteristic, the absorption of hydrophilic compounds was negatively affected in a manner that no symptoms in the leaves of target were observed (Fig. 3).

Plant height was suppressed in some treatments, mainly in the T14 and T8 with a reduction around $36 \%$ in comparison with control. Comparing the treatments containing bioherbicide + adjuvants with those using adjuvants + water (Fig. 4), it is observed that the application of only adjuvants have no suppressive effect on the growth of target plants $(p<0.05)$. A similar result was found by Gronwald et al. (2002) wherein evaluating the single use of Silwet L-77 adjuvant on the control of Cirsium arvense plants, a reduction in height of these plants was not observed. However, when used in a formulation with Pseudomonas syringae pv. tagetis verified a reduction of $31 \%$ in plant height.

Some treatments showed significant effects on dry matter of target, mainly T14 that presented a reduction of $36.8 \%$ compared to control. The application of $100 \%$ bioherbicide caused reduction close to $31 \%$ in dry matter; however, when evaluating the phytotoxicity, only small chlorotic scores in the leaves were verified (Fig. 5). The comparison of the dry matter of plants treated with water, water + adjuvants and bioherbicide + adjuvants are presented in Fig. 6. In treatments 3, 4, 5, 6, 7, 11, 12, 13, 16 and 17 the dry mass of water + adjuvants was close to average obtained in the plants treated with water, suggesting that the dry matter reduction effect is mainly caused by Diaporthe sp. phytotoxins.

\section{Conclusions}

The microorganism Diaporthe sp. showed potential for use as post-emergence herbicide and its efficiency was enhanced by using adjuvants in the formulation. The formulation containing $5.5 \mathrm{wt} \%$ of palm oil, $5.5 \mathrm{wt} \%$ of adjuvants and HLB 15.0 resulted in the highest efficiency of bioherbicide, which was three times higher than the 
Fig. 6 Dry matter of plants (g) obtained in the 17

formulations and its comparison with treatments using water and water + adjuvants. Same letter in the column did not differ statistically by the Scott-Knott's test at $95 \%$ of confidence level $(p<0.05)$
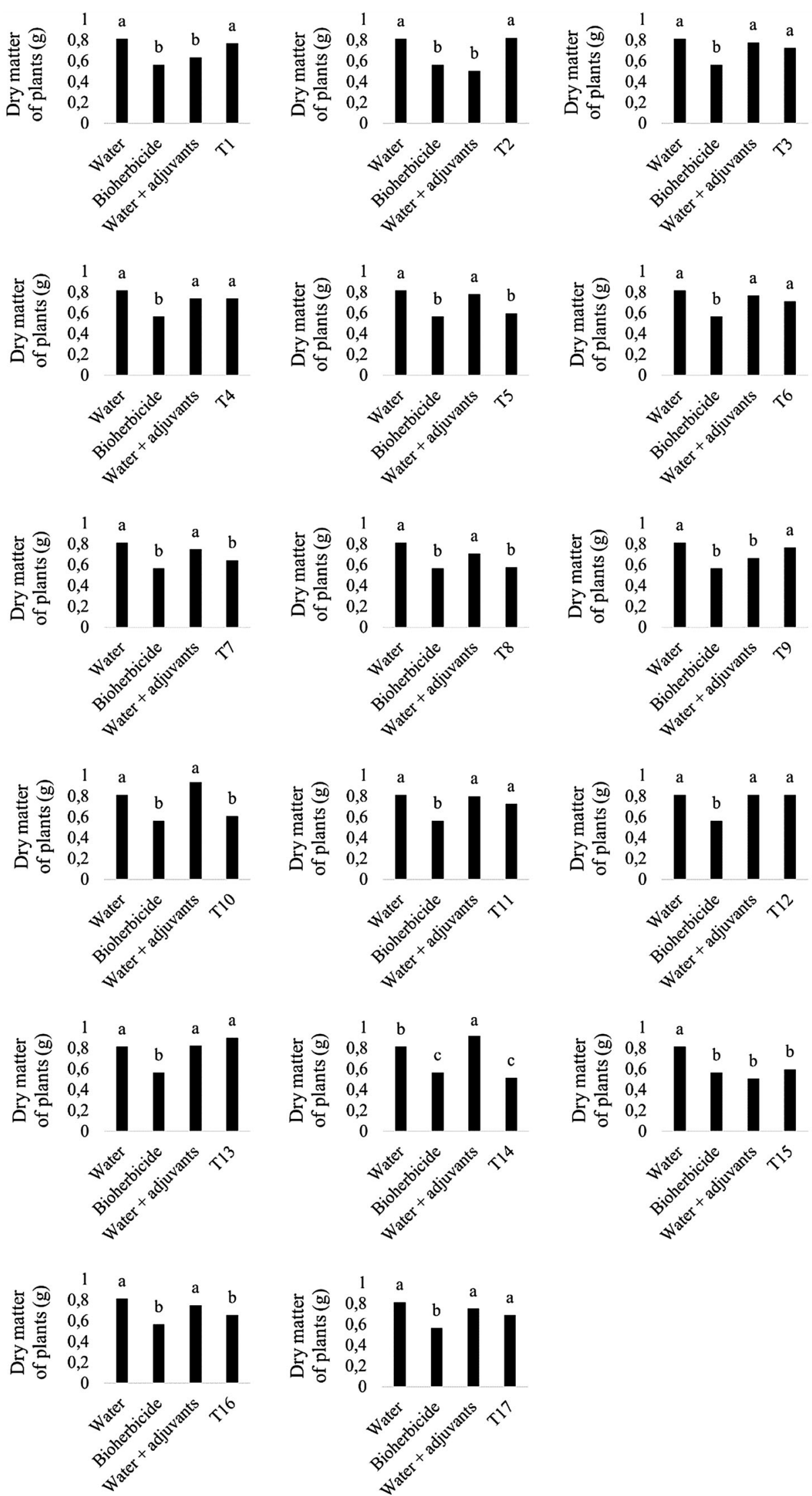
unformulated product. Among the surfactants tested, Tween ${ }^{\circledR} 80$ was responsible for increasing the efficacy of the formulation.

Acknowledgements The authors thank CNPq and the State Department of Development and Investment Promotion (SDPI-RS) for the financial support of this work. Funding was provided by Conselho Nacional de Desenvolvimento Científico e Tecnológico (Grant no. 303482/2015-0) and Secretaria de Desenvolvimento Econômico, Ciência, Tecnologia e Inovação (Grant no. 22/2012).

\section{Compliance with ethical standards}

Conflict of interest The authors declare that there is no conflict of interest.

\section{References}

Behrens RW (1964) The physical and chemical properties of surfactants and their effects on formulated herbicides. Weeds $12: 255-258$

Briscoe WE (2014) Identification of a phytotoxic fungus and an investigation into the isolation of its phytotoxic constituents. University of Mississippi, Tesis

Brun T, Rabuske JE, Todero I, Almeida TC, Daniel Junior JJ, Ariotti G, Confortin T, Arnemann JA, Kuhn RC, Guedes JVC, Mazutti MA (2016) Production of bioherbicide by Phoma sp. in a stirred-tank bioreactor. 3 Biotech 6:230. doi:10.1007/s13205$016-0557-9$

Charudattan R (2001) Biological control of weeds by means of plant pathogens: significance for integrated weed management in modern agro-ecology. Biocontrol 46:229-260

Chutia M, Mahanta JJ, Bhattacharyya N, Bhuyan M, Boruah P, Sharma TC (2007) Microbial herbicides for weed management: prospects, progress and constrains. Plant Pathol J 6:200-218

Cimmino A, Masi M, Evidente M, Superchi S, Evidente A (2015) Fungal phytotoxins with potential herbicidal activity: chemical and biological characterization. Nat Prod Rep 32:1629-1653

Cordeau S, Triolet M, Wayman S, Steinberg C, Guillemin JP (2016) Bioherbicides: dead in the water? A review of the existing products for integrated weed management. Crop Prot 87:44-49

Dayan FE, Duke SO (2014) Natural compounds as next-generation herbicides. Plant Physiol 166:1090-1105

Duke SO, Dayan FE (2015) Discovery of new herbicide modes of action with natural phytotoxins. Discov Synth Crop Prot Prod 1204:79-92

European Weed Research Council. Report of the 3rd and 4rd meetings of EWRC (1964) Comittes of Methods in Weed Research. Weed Res 4:88
Gronwald JW, Plaisance KL, Ide DA, Wyse D (2002) Assessment of Pseudomonas syringae pv. tagetis as a biocontrol agent for Canada thistle. Weed Sci 50:397-404

Harding DP, Raizada MN (2015) Controlling weeds with fungi, bacteria and viruses: a review. Front Plant Sci 6:659

Hess FD, Foy CL (2000) Interaction of surfactants with plant cuticles. Weed Technol 14:807-813

Mascarin GM, Jaronski ST (2016) The production and uses of Beauveria bassiana as a microbial insecticide. World J Microbiol Biotechnol 32:177

Pandey A (2003) Solid-state fermentation. Biochem Eng J 13:81-84

Pes MP, Mazutti MA, Almeida TC, Curioletti LE, Melo AA, Guedes JVC, Kuhn RC (2016) Bioherbicide based on Diaporthe sp. secondary metabolites in the control of three tough weeds. Afr J Agric Res (accepted 2016)

Prada H, Ávila L, Sierra R, Bernal A, Restrepo S (2009) Caracterización morfológica y molecular del antagonismo entre el endófito Diaporthe sp. aislado de frailejón (Espeletia sp.) y el fitopatógeno Phytophthora infestans. Rev Iberoam Micol 26:198-201

Sanghi A, Garg N, Sharma J, Kuhar K, Kuhad RC, Gupta VK (2008) Optimization of xylanase production using inexpensive agroresidues by alkalophilic Bacillus subtilis ASH in solid-state fermentation. World J Microb Biotechnol 24:633-640

Santos PJC, Savi DC, Gomes RR, Goulin EH, Da Costa Senkiv C, Tanaka FA, Almeida ÁM, Galli-Terasawa L, Kava V, Glienke C (2016) Diaporthe endophytica and D. terebinthifolii from medicinal plants for biological control of Phyllosticta citricarpa. Microbiol Res 186:153-160

Selvakumar P, Pandey A (1999) Solid state fermentation for the synthesis of inulinase from Staphylococcus sp. and Kluyveromyces marxianus. Process Biochem 34:851-855

Souza ARC, Baldoni DB, Lima J, Porto V, Marcuz C, Ferraz RC, Kuhn RC, Jacques RJS, Guedes JVC, Mazutti MA (2015) Bioherbicide production by Diaporthe sp. isolated from the Brazilian Pampa biome. Biocatal Agric Biotechnol 4:575-578

Souza ARC, Baldoni DB, Lima J, Porto V, Marcuz C, Machado C, Ferraz RC, Kuhn RC, Jacques RJS, Guedes JVC, Mazutti MA (2016) Selection, isolation, and identification of fungi for bioherbicide production. Braz J Microbiol. doi:10.1016/j.bjm. 2016.09.004

Specian V, Sarragiotto MH, Pamphile JA, Clemente E (2012) Chemical characterization of bioactive compounds from the endophytic fungus Diaporthe helianthi isolated from Luehea divaricata. Braz J Microbiol 43:1174-1182

Varejão EVV, Demuner AJ, Barbosa LCA, Barreto RW (2013) The search for new natural herbicides e Strategic approaches for discovering fungal phytotoxins. Crop Protec 48:41-50

Weaver MA (2009) Improved bioherbicidal efficacy by Myrothecium verrucaria via spray adjuvants or herbicide mixtures. Biol Control 50:150-156 